\title{
Attachment of the Synapse-Specific Phosphoprotein Protein I to the Synaptic Membrane: A Possible Role of the Collagenase-Sensitive Region of Protein I
}

\author{
Tetsufumi Ueda \\ Mental Health Research Institute and the Departments of Psychiatry and Pharmacology, \\ The University of Michigan, Ann Arbor, Michigan 48109, U.S.A.
}

\begin{abstract}
The purified synapse-specific phosphoprotein Protein I was previously shown to be degraded by a bacterial collagenase, through a series of intermediates, to a collagenase-resistant fragment of molecular weight about 48,000 containing a phosphorylated serine residue. In this study, a purified synaptic membrane fraction containing Protein I was treated with $\mathrm{Cl}$. histolyticum collagenase; membrane-bound and membrane-free proteins were then phosphorylated using $\left[\gamma^{32} \mathrm{P}\right] \mathrm{ATP}$ and analyzed by SDS-polyacrylamide gel electrophoresis and autoradiography. It was observed that Protein I bound to the synaptic membrane was susceptible to the collagenase and degraded to fragments of molecular weights about $68,000,62,000$, and 48,000; the 68,000 fragment remained bound to the membrane whereas the 62,000 and 48,000 fragments were dissociated from the membrane. These observations suggest that the peptide moiety of mol. wt. 6000 , present in the 68,000 fragment but absent from the 62,000 fragment, may play a crucial role in anchoring Protein I to the synaptic membrane. Key Words: Cyclic AMP-regulated phosphoprotein-Protein I-Synaptic membrane-Collagenase sensitivity. Ueda $T$. Attachment of the synapse-specific phosphoprotein Protein I to the synaptic membrane: A possible role of the collagenase-sensitive region of Protein $I$. J. Neurochem. 36, 297-300 (1981).
\end{abstract}

There is mounting evidence to suggest that cyclic nucleotides and phosphorylation of specific proteins may play important roles in the function of the nervous system (Bloom, 1975: Daly, 1977; Greengard, 1978). Protein la (mol. wt. $=86,000)$ and Protein Ib (mol. wt. $=80,000$ ), collectively referred to as Protein I because of highly similar properties (Ueda and Greengard, 1977), are principal endogenous substrates for cyclic AMP-dependent protein kinase in subcellular fractions enriched in synaptic junctional membranes (Ueda and Greengard, 1977; Kelly et al., 1979: DeBlas et al., 1979). Recent immunocytochemical (Bloom et al., 1979) as well as biochemical (Ueda et al., 1979) evidence indicates that Protein $I$ is present in the synaptic vesicle, junctional membrane, and post- synaptic density of certain types of synapses. Purified Protein I contains Protein Ia and Protein Ib (in an approximate ratio of $1: 2$ ), both rich in glycine and proline and highly elongated. Both of these proteins are degraded by collagenase to a fragment of molecular weight about 48,000 , which is resistant to further degradation and contains a specific serine residue phosphorylated by cyclic AMP-dependent protein kinase (Ueda and Greengard, 1977). Recently, it was shown that Protein I comprises a globular, collagenase-resistant region and an elongated, collagenase-sensitive region (Ueda and Greengard, unpublished results). In view of evidence that acetylcholinesterase consists of a collagenase-resistant, globular head and a collagen-like, elongated tail (Rieger et al.,
Received February 27, 1980; accepted June 30, 1980.

Address correspondence and reprint requests to Tetsufumi
Ueda, Mental Health Research Institute, The University of Michigan, 205 Washtenaw Place, Ann Arbor, Michigan 48109. Abbreviation used: SDS, Sodium dodecylsulfate. 
1973: Dudai and Silman, 1974; Lwebuga-Mukasa et al., 1976: Rosenberry and Richardson, 1977) and that the collagenous, elongated moiety may be involved in anchoring the enzyme to some membrane structure (Hall and Kelly, 1971; Dudai and Silman, 1974; LwebugaMukasa et al., 1976), the possible role of the collagenasesensitive moiety of Protein I in anchoring Protein I to the synaptic membrane was investigated in the present study. The results indicate that a peptide moiety of mol. wt. 6000 present in the collagenase-sensitive region may play a crucial role in the attachment of Protein $I$ to the synaptic membrane.

\section{MATERIALS AND METHODS}

Fresh bovine brains were obtained from a local slaughter house, transported on ice to the laboratory, and processed immediately. A synaptic membrane fraction (lower synaptic membrane fraction) was prepared from bovine cortex as described previously (Ueda et al., 1979). Protein I was purified to apparent homogeneity from bovine cerebral cortices by the method of Ueda and Greengard (1977). A highly purified collagenase (Clostridium histolytic $\mathrm{um}$ collagenase, form III) was purchased from Advance Biofactures Corp. (Lynbrook, New York); $\left[\gamma_{-}{ }^{32} \mathrm{P}\right]$ ATP $(3000 \mathrm{Ci} / \mathrm{mmol})$ from New England Nuclear (Boston, Massachusetts): ATP from Sigma Chemical Company (St. Louis, Missouri): isobutyl methylxanthine from Calbiochem (San Diego, California): and sucrose from Fisher (Pittsburgh. Pennsylvania). The synaptic membrane fraction $(550 \mu \mathrm{g})$ was incubated at $30^{\circ}$ in the absence or presence of collagenase ( 32 or 320 units) in $12.5 \mathrm{~mm}$-Tris- $\mathrm{HCl}(\mathrm{pH} 7.4)$ buffer containing $6 \mathrm{mM}^{-\mathrm{CaCl}_{2}}$ (final volume, $0.2 \mathrm{ml}$ ). After 5 or $10 \mathrm{~min}$, the incubation mixture was chilled to $0^{\circ}$ and immediately centrifuged at $150,000 \times g$ for $30 \mathrm{~min}$ at $4^{\circ}$; both the pellet and supernatant fractions from the treated membrane fraction were used in phosphorylation reactions. The resulting pellet was suspended in $0.2 \mathrm{ml}$ of distilled water and aliquots ( 30 $\mu$ l) were incubated at $30^{\circ}$ for $10 \mathrm{~s}$ in the absence or presence of $10 \mu \mathrm{M}$ cyclic AMP, in the presence of $50 \mathrm{mM}$ sodium morpholinoethane sulfonate (MES) buffer $(\mathrm{pH}$ 6.2), $10 \mathrm{~mm}-\mathrm{MgCl}_{2}, 1 \mathrm{~mm}$-isobutyl methylxanthine, and 4 $\mu \mathrm{M}-\left[\gamma^{-32} \mathrm{P}\right] \mathrm{ATP}(15 \mathrm{Ci} / \mathrm{mmol}, \mathrm{pH}$ adjusted to 7.0 with Tris base). Aliquots $(30 \mu \mathrm{l})$ of the resulting supernatant fraction were incubated at $30^{\circ}$ for $30 \mathrm{~min}$, in the absence or presence of $10 \mu \mathrm{M}$ cyclic AMP, in the presence of 50 mM-sodium 4-(2-hydroxyethyl)-1-piperazineethane sulfonate (HEPES), $10 \mathrm{~mm}-\mathrm{MgCl}_{2}, 5$ units of Protein I kinase [prepared from bovine brain through step 3 of the procedure of Uno et al. (1977)], and $1 \mu \mathrm{M}-\left[\gamma^{-32} \mathrm{P}\right]$ ATP $(15 \mathrm{Ci} /$ $\mathrm{mmol}, \mathrm{pH} 7.0$ ). The phosphorylation reactions were terminated by the addition of $50 \mu \mathrm{l}$ of "sodium dodecyl sulfate (SDS) stop solution" containing 9\% SDS, 6\% $\beta$ mercaptoethanol, $15 \%$ glycerol, and a small amount of bromphenol blue dye in $0.186 \mathrm{M}$-Tris- $\mathrm{HCl}(\mathrm{pH} \mathrm{6.7)}$. The phosphorylated proteins were separated by SDSpolyacrylamide gel $(6.9 \%)$ electrophoresis and visualized by autoradiography, as described previously (Ueda and Greengard, 1977). Protein was determined by the method of Lowry et al. (1951) with bovine serum albumin as protein standard.

\section{RESULTS AND DISCUSSION}

The synaptic membrane fraction was first treated with a highly purified collagenase, and membrane-bound and membrane-free proteins including fragmented polypeptides were then subjected to phosphorylation by endogenous kinase and exogenous kinase, respectively, in the presence of $\left[\gamma_{-}^{32} \mathrm{P}\right]$ ATP. Preliminary studies indicated that collagenase-fragmented polypeptides derived from purified Protein I retained the ability to serve as substrate for cyclic AMP-dependent protein kinase. Collagenasecatalyzed proteolysis of phosphorylatable proteins in the synaptic membrane fraction is shown in Fig. 1. Cyclic AMP markedly stimulated the phosphorylation of Protein Ia $(\mathrm{mol}$. wt. $=86,000$ ), Protein Ib (mol. wt. $=80,000$ ), Protein IIa (mol. wt. $=56,000)$, Protein IIb $(\mathrm{mol}$. wt. $=$ 52,000 ), and two additional proteins (mol. wt. $=76,000$ and 65,000 ) by endogenous protein kinase(s) (Fig. 1, A or B, lanes 1 and 2; Lohmann et al., 1978). In addition, moderate stimulation by cyclic AMP was observed on a number of other proteins which have molecular weights higher than those of Proteins Ia and Ib. Among the phosphorylatable proteins, Proteins Ia and Ib were the most sensitive to the collagenase treatment; both of these proteins bound to the membrane were degraded, as were highly purified Proteins Ia and Ib, through intermediate polypeptides, designated fragment $\mathrm{I}_{68}$ (mol. wt. $=68,000$ ) and fragment $I_{62}$ (mol. wt. $\left.=62,000\right)$ to an apparently collagenase-resistant fragment, fragment $I_{48}(\mathrm{~mol}$. wt. $=$ 48,000 ). Although the 65,000 protein and some minor phosphoproteins of high molecular weights were also susceptible to collagenase to some degree, the 76,000 protein, Proteins Ila and Ilb, and other minor phosphoproteins in the synaptic membrane fraction were virtually resistant to the collagenase treatment (compare lane 2 and lane 4 in Fig. 1, A or B). Moreover, collagenase had no significant effect on any of the proteins, except on Proteins Ia and Ib, which were visualized by Coomassie blue staining (Fig. 1, B, lower part).

The observation that membrane-bound Proteins Ia and Ib accepted phosphate from exogenously added ATP and were accessible to the action of collagenase indicates that the phosphate-accepting moiety of these proteins which is collagenase-resistant and the collagenase-sensitive moiety are both exposed to the exterior of the membrane. This is compatible with the notion that Proteins Ia and Ib in the synaptic membrane are "extrinsic protein," a notion based upon the observation that these proteins were easily extracted from the membrane with EGTA or salts such as $\mathrm{NH}_{4} \mathrm{Cl}$ (Ueda and Greengard, 1977; Ueda et al., 1979).

It may be noted that when membrane-bound Proteins Ia and $I b$ were degraded to fragment $I_{62}$ or fragment $I_{48}$, these fragments were readily released from the membrane, while fragment $l_{68}$ remained bound to the membrane (compare lane 4 and lane 8 in Fig. 1, A). Fragment $I_{68}$ present in the supernatant (Fig. 1, A, lane 8) might have derived from small amounts of Proteins Ia and Ib initially present in the supernatant (Fig. 1, A, lane 6), or it may be fragment $I_{68}$ released from the membrane, or may represent botli. In either case, the amount of membranebound form is greater than that of membrane-free form (compare lane 4 and lane 8 in Fig. 1, A), indicating that fragment $I_{68}$, like Proteins $I a$ and $I b$, has a strong affinity 
A Incomplete Fragmentation

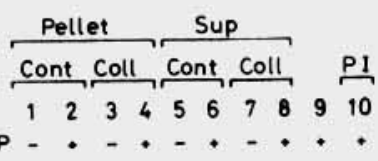

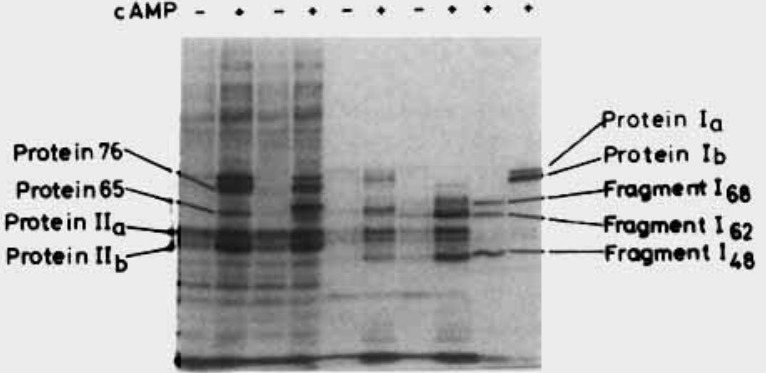

FIG. 1. Fragmentation by collagenase of Protein la and Protein $\mathrm{lb}$ in a synaptic membrane fraction, and subsequent release of their fragments from the membrane. A synaptic membrane fraction [lower synaptic membrane fraction of Ueda et al. (1979)] was treated with (lanes 3, 4, 7, 8) or without (lanes $1,2,5,6)$ collagenase (A, 32 units, 5 min; $\mathbf{B}, 320$ units, $10 \mathrm{~min}$ ), and centrifuged at $150,000 \times \mathrm{g}$ for $30 \mathrm{~min}$. Membrane-bound (lanes 1-4) and membrane-free polypeptides were phosphorylated by endogenous and exogenous protein kinase, respectively, separated by SDS-gel electrophoresis, and visualized by autoradiography (A; B, upper part), and Coomassie blue staining ( $B$, lower part), as described in Materials and Methods. The phosphorylation reaction was carried out in the absence $(-)$ or presence $(+)$ of cyclic AMP. Cont, control; Coll, collagenase-treated. Purified [ $\left.{ }^{32} P\right]$ -
phosphoprotein I (PI) and various phosphopeptide fragments-fragment $I_{68}$, fragment $I_{62}$, and fragment $I_{48}$, which were made by a collagenase treatment of [ ${ }^{32}$ PJphosphoprotein I-were included as markers (lanes 9 and 10). for the membrane. On the contrary, in the case of fragment $I_{6: 2}$, the amount of membrane-free form was far greater than that of membrane-bound form (compare lane 4 and lane 8 in Fig. 1, A), indicating that fragment $I_{62}$ has lost, or been substantially reduced in, the ability to bind to the membrane, a property which was possessed by its precursors, fragment $\mathrm{I}_{6 \mathrm{x}}$, Protein Ia, and Protein Ib. By a similar argument, it can also be concluded that fragment $\mathrm{I}_{48}$ has little ability to bind to the membrane (compare lane 4 and lane 8 in Fig. 1, A or B). Little or no fragment $I_{62}$ was found in the supernatant under the conditions that allowed extensive proteolysis (Fig. 1, B, lane 8). This is most likely due to further conversion of fragment $I_{62}$ to fragment $\mathrm{I}_{4 \times}$.

The argument above is summarized schematically in Fig. 2. Although kinetic constants for each step are yet to be determined, the scheme suggests that the peptide moiety of molecular weight about 6000 , which is contained in fragment $I_{68}$ but is excluded from fragment $I_{62}$, may play a crucial role in anchoring Protein I to the synaptic membrane (or a membrane-bound specific protein). The 6,000

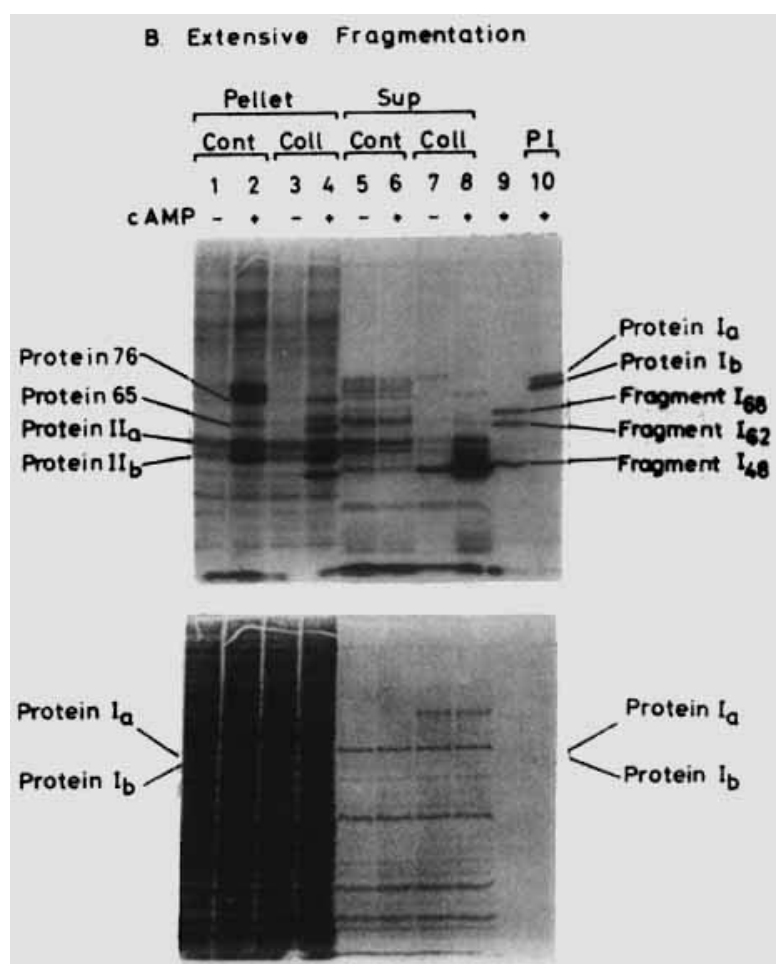

Cont Coll Cont Coll $\frac{\text { S1 }}{10}$

MP - $-.+-\cdot-\cdot \cdot \cdot$ the $\mathrm{NH}_{2}$ terminal and Pro-X-COOH at the $\mathrm{COOH}$ terminal (where $X$ and $Y$ can be any amino acid), since Clostridium histolyticum collagenase (form III, which was used in the present study) is known to cleave specifically the amide bond between $\mathrm{X}$ and Gly of the sequence Pro$X$-Gly-Pro- $Y$ present in collagen to Pro- $X-\mathrm{COOH}$ and $\mathrm{NH}_{2}$-Gly-Pro-Y (Harper and Kang, 1970; LwebugaMukasa et al., 1976).

The observations reported here suggest that the collagenase-sensitive region of Protein I contains a fragment of mol. wt. 6000 , which appears to be essential for the attachment of Protein I to the synaptic membrane.

\section{ACKNOWLEDGMENT}

This work was supported by USPHS Grant NS 15113. The author thanks Robert Rosenbaum for valuable technical assistance.

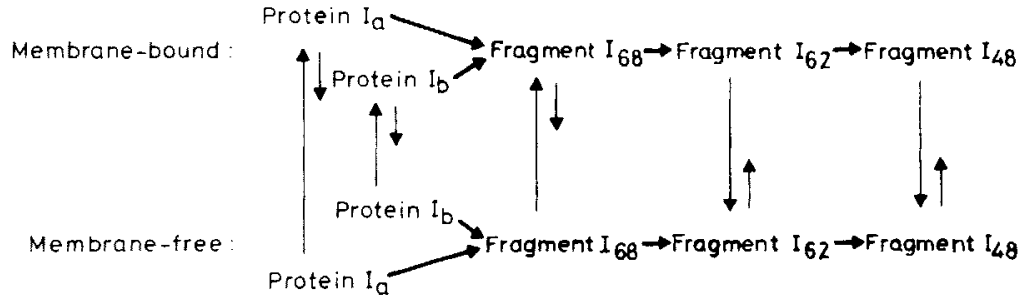

FIG. 2. Diagram indicating steps through which membrane-bound Proteins la and lb are converted to membrane-free fragment $\mathrm{I}_{48}$. This diagram was made based upon the observation shown in Fig. 1. Heavy arrows indicate collagenasecatalyzed proteolytic steps. Light arrows indicate dissociation and association of the polypeptides from and to the membrane. 


\section{REFERENCES}

Bloom F. E. (1975) Role of cyclic nucleotides in central synaptic functions. Rev. Physiol. Biochem. Pharmacol. 74, 1-103.

Bloom F. E., Ueda T., Battenberg E., and Greengard P. (1979) Immunocytochemical localization, in synapses, of protein $I$, an endogenous substrate for protein kinases in mammalian brain. Proc. Natl. Acad. Sci. USA 76, 5982-5986.

Daly J. W. (1977) The formation, degradation, and function of cyclic nucleotides in the nervous system. Int. Rev. Neurobiol. 20, 105-168.

DeBlas A. L., Wang Y-J., Sorensen R., and Mahler H. R. (1979) Protein phosphorylation in synaptic membranes regulated by adenosine $3^{\prime}: 5^{\prime}$-monophosphate: Regional and subcellular distribution of the endogenous substrates. $J$. Neurochem. 33, 647-659.

Dudai Y. and Silman I. (1974) The effects of solubilization procedures on the release and molecular state of acetylcholinesterase from electric organ tissue. J. Neurochem. 23, $1177-1187$

Greengard P. (1978) Cyclic Nucleotides, Phosphorylated Proteins and Neuronal Functions. Raven Press, New York.

Hall Z. W. and Kelly R. B. (1971) Enzymatic detachment of endplate acetylcholinesterase from muscle. Nature 232, $62-63$.

Harper E. and Kang A. M. (1970) Studies on the specificity of bacterial collagenase. Biochem. Biophys. Res. Commun. 41, $482-487$.

Kelly D. T., Cotman C. W., and Largen M. (1979) Cyclic AMPstimulated protein kinases at brain synaptic junctions. $J$. Biol. Chem. 254, 1564-1575.

Lohmann S. A., Ueda T., and Greengard P. (1978) Ontogeny of synaptic phosphoproteins in brain. Proc. Natl. Acad. Sci. USA 75, 4037-4041.

Lowry O. H., Rosebrough N. J., Farr A. L., and Randall R. J. (1951) Protein measurement with the Folin phenol reagent. J. Biol. Chem. 193, 265-275.

Lwebuga-Mukasa J. S., Lappi S., and Taylor P. (1976) Molecular forms of acetylcholinesterase from Torpedo californica: Their relationship to synaptic membranes. Biochemistry 15 , $1425-1434$.

Rieger F., Bon S., Massoulié J., and Cartaud J. (1973) Observation par microscopie électronique des formes allongées et globulaires de l'acetylcholinesterase de gymnote (Electrophorus électricus). Eur. J. Biochem. 34, 539-547.

Rosenberry T. and Richardson J. M. (1977) Structure of 18 S and $14 S$ acetylcholinesterase. Identification of collagen-like subunits that are linked by disulfide bonds to catalytic subunits. Biochemistry 16, 3550-3558.

Ueda T. and Greengard P. (1977) Adenosine 3':5'monophosphate-regulated phosphoprotein system of neuronal membranes. I. Solubilization, purification and some properties of an endogenous phosphoprotein. J. Biol. Chem. $252,5155-5163$.

Ueda T., Greengard P., Berzins K., Cohen R. S., Blomberg F., Grab D. J., and Siekevitz P. (1979) Subcellular distribution in cerebral cortex of two proteins phosphorylated by a cAMP-dependent protein kinase. J. Cell Biol. 83, 308-319.

Uno T., Ueda T., and Greengard P. (1977) Adenosine 3':5'. monophosphate-regulated phosphoprotein system of neuronal membranes. II. Solubilization, purification and some properties of an endogenous adenosine $3^{\prime}: 5^{\prime}$. monophosphate-dependent protein kinase. J. Biol. Chem. 252, 5164-5174. 